\title{
Level of Community Participation for Sustainable Forest Management in Bojonegoro Regency
}

\author{
Ekky Silvia Anggraeni ${ }^{1}$, Jati Batoro ${ }^{2}$, Rita Parmawati $^{3}$ \\ \{silviaekky@gmail.com ${ }^{1}$ \} \\ Universitas Brawijaya, Indonesia ${ }^{1,2,3}$
}

\begin{abstract}
A sustainable forest is a management for the process of forest preservation, so it can improve the production and services continuously, but does not reduce the function of the forest and does not cause environmental impact. This research aimed to analyze the level of community participation to manage sustainable forests in Bojonegoro Regency. The method used in this research was quantitative descriptive with the population sample was people of Bojonegoro Regency. The sampling technique used was purposive. Results indicate that the highest contribution score in the planning program is shown by the citizen power group $(80 \%)$ and the tokenism group $(56 \%)$ and the nonparticipation group (36\%). In the monitoring and evaluation program, the citizen power group, achieve the highest score with $80 \%$ and $90 \%$. Then the tokenism group is $60 \%$ and $50 \%$, and the non-participation group has the lowest with $10 \%$ and $30 \%$. It shows that the forest community development in Bojonegoro Regency was based on participatory and involved in forest development on the form of representation at various program stages such as planning, implementation, and monitoring evaluation. The community was also involved in the decision making of the development, so the community involvement in community forest development mostly was tokenism, and a small portion was in the form of citizen power and non-participation group.
\end{abstract}

Keywords: Sustainable Forest, Community Participation, Community Forest, Arnstein.

\section{Introduction}

Indonesia located on the equator, so it has a functional area for soil fertility and has a large forest area. Indonesia's forest area was around 120.6 million hectares in 2017. However, this amount is higher than the amount of deforestation in 2012-2017 as follows, 0.34 Million Ha in 2012-2013; 0.29 Million Ha in 2013-2014; 0.82 Million Ha in the year 2014-2015; 0.43 Million Ha in 2015-2016; and 0, 30 million hectares in 2016-2017 [1].

Forests have direct and indirect benefits for life. Timber and non-wood products such as honey, rattan has a direct benefit for the community. While indirect benefits such as environmental services in the form of oxygen, absorption of carbon dioxide, stabilizing the climate, plants, and animal habitats. It also has a consumptive and non-consumptive function. The consumptive function of the forest is a need for wood as fuel, buildings, sources of gardening and farming. Non-consumptive functions of the forest include oxygen, water regulation, erosion prevention, and stabilizing the climate [2].

Social Forestry is an activity that is needed to reduce inequality in management or the utilization of forest areas to reduce unemployment and poverty in the community around the forest by providing legal access in utilization through the Community Forest (HKm) program 
on state forest land [3]. Conducted by local communities or law communities as the primary support system to improve their welfare, environmental balance, and socio-cultural dynamics in the form of village forests, Social forests, community forest plantations, traditional forests, and partnership forest [4].

Forest for the people is a way of looking at the social forestry of management that carried out the sustainability of the community around the forest area or customary forest/forest rights [5]. Communities around the forest get a permit or the right to take advantage of the forest so that they get a decent living; in this way, it can reduce forest encroachment [6]. Social Forestry aims to increase capacity and provide access to communities to manage forests to solve economic and social problems that occur in the community [7].

Implementation of social forestry programs in Bojonegoro Regency has several obstacles, including the community are not planting forestry plants in the management area, has destruction of forest stands, Majority of social forestry management areas are planted only with crops. It can cause the sustainability of social forestry in Bojonegoro Regency is not running optimally, so it is necessary to analyze the level of community participation in the Bojonegoro District Social Forestry program.

The choice of location is based on consideration based on the vision of Bojonegoro Regency, which is improving welfare based on people's economy. Geographically based on Bojonegoro Regency 40\% is a Production Forest area with an area of 94,479.34 Ha and people living around the forest make an IPHPS proposal so that they can use the forest as an economic source. It is necessary to have an assessment in the utilization of natural resources to realize the vision of Bojonegoro Regency based on the sustainable use of natural resources. Bojonegoro Regency has several potentials including biological, animal, and mineral resources. The biological resources include of rops, tobacco, cloves, teak. The animal resources, include of cattle, goat, chicken, catfish. The mineral resource includes of mineral oil and natural gas resources.

\section{Research Methods}

\subsection{Study Area}

Bojonegoro Regency's social forestry located in two subdistricts, namely Ngraho District and Margomulyo District. Geographically, Ngraho Subdistrict was on the north of Margomulyo Subdistrict and directly adjacent to Ngawi and Blora Regency. Bengawan Solo drained both districts for irrigation. The location of the Social Forestry area was between the two sub-districts. The Social Forestry Area had an area of 823 hectares and located in the forest area of Perum Perhutani KPH Padangan with a majority of teak forest plants (Tectona grandis). The location chosen was based on Bojonegoro Regency's considerations to improved welfare on people's economy. Geographically, $40 \%$ of Bojonegoro Regency was a Production Forest area $(94,479,34 \mathrm{Ha})$. Around the forest area, there was a community that lived there. The Communities were proposing for the Social Forest program so they can use the forest as a financial source and improve community welfare.

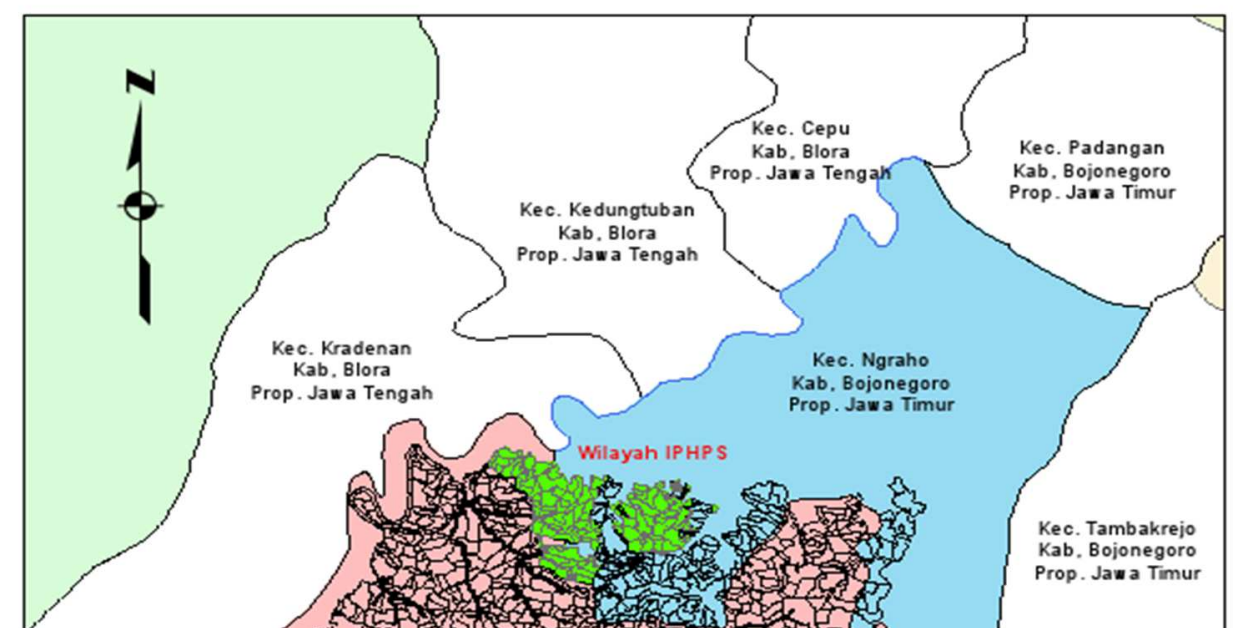


Description:

Fig. 1. Social Forestry Study Area.

a) Social Forestry

\section{Data Analisys}

This research was conducted in the area of social forestry development in Bojonegoro Regency. Site selection was determined by purposive sampling with consideration of social forestry areas in Production Forest Areas that were spread out in administrative areas in Bojonegoro Regency, the selected sub-districts, namely Margomulyo District and Ngraho District as samples. The overall number of respondents was determined by a side quota of $2 \%$ of the total number of farmers in the Production Forest Community in Bojonegoro Regency. Thus, the number of respondents was 107 people. Other respondents were experts determined by the search method. The number of experts who became respondents was determined later based on their involvement in the construction of the Community Forest and was sourced from the government, NGOs, universities, and the private sector.

The survey was conducted with a questionnaire, and in-depth interviews that were prepared in-depth were done reflectively/subjectively to find the dominant factors that determine the problem or problem and provide an interpretation of the current problem. Participation rates were measured using the Arnstein participatory ladder and Likert scale scoring (1-5). 


\section{Result and Discussion}

Table 1. Level of Community Participation in Community Forest Development in Production Forest Areas in Bojonegoro Regency

\begin{tabular}{|l|c|c|c|c|c|c|c|c|}
\hline \multirow{2}{*}{$\begin{array}{c}\text { Participation } \\
\text { rate }\end{array}$} & \multicolumn{4}{|c|}{ Average Participation Score } & \multicolumn{2}{c|}{$\begin{array}{c}\text { Participation } \\
\text { Pchievement }\end{array}$} \\
\cline { 2 - 9 } & Score & $\mathbf{\%}$ & Score & $\mathbf{\%}$ & Score & $\mathbf{\%}$ & Score & $\%$ \\
\hline Low $(\mathrm{n}=26)$ & 9 & 36 & 10 & 40 & 3 & 30 & 23 & 38,33 \\
\hline Medium (n=63) & 14 & 56 & 15 & 60 & 5 & 50 & 34 & 56,67 \\
\hline High $(\mathrm{n}=18)$ & 20 & 80 & 20 & 80 & 9 & 90 & 49 & 81,67 \\
\hline Average & 14 & 56 & 15 & 60 & 5 & 50 & 34 & 56,67 \\
\hline
\end{tabular}

Information:

$\%=$ Achievement of maximum score ( 25 for planning, 25 for implementation and 10 for monitoring)

$\mathrm{n}=$ Number of responses

The table above shows that the distribution of achievement scores in each program is relatively high (56\%) for planning programs, $60 \%$ for implementation programs, and $50 \%$ for monitoring and evaluation programs. However, this value varied with each group of participants. The highest score achieved in the planning program showed in the citizen power group (80\%) and the tokenism group (56\%) and the non-participation group (36\%). Likewise, the conditions in the implementation and monitoring and evaluation program, namely the citizen power group, had the highest score of $80 \%$ and $90 \%$. Then the tokenism group is $60 \%$ and $50 \%$, and vice versa, the non-participation group, has the lowest score in the implementation and monitoring and evaluation program, which is $10 \%$ and $30 \%$.

From this condition is shown that community forest development in Bojonegoro Regency is participatory, in the sense that Community Forest development has involved the community as community forest managers in the form of representation at various stages of the program such as planning, implementation, and monitoring and evaluation. The community is also involved in making development decisions. The nature of community involvement in the development of Community Forests is that most tokenism and a small portion are in the form of citizen power and non-participation.

Tokenism participation (58.68\%), such as the range of decision authority or participation of Pesanggem community, ranging from getting information, giving advice to the government, negotiating, and engaging in development decision making both in the planning, implementation and monitoring and evaluation stages. Then $16.82 \%$ of the community has control or authority in making HKm or citizen power development decisions, and vice versa, around $24.30 \%$ of the Pesanggem community is at the non-participation level, ie, the community is not involved in decision making. Pesanggem society is only as an object of development or in other words, that the government only heals or educates the community.

There are several classified indications of Pesanggem community. Low participation (non-participation) has a score achievement in every development activity (planning, implementation, and monitoring), which is also lower when compared to the Pesanggem group, which has a higher level of participation. Indications give meaning that the authority in decision making for participation for non-participation groups is limited, especially in planning and monitoring activities, which is less than $40 \%$. However, the assessed comparison of achievement scores between activities (planning, implementation and monitoring) for all groups of Pesanggem (low, medium and high), it is seen that the highest decision making 
authority in the program implementation, then planning, and evaluation, except for Pesanggem groups with high participation categories which have achieved the participation score in all programs more than $80 \%$.

The distribution of achievement scores means that the highest freedom to decide on participation is in the implementation program, then planning, and evaluation. It is undoubtedly related to the characteristics of the Community Forest development project, which is more freeing Pesanggem communities in the implementation of the program meanwhile, the involvement and authority of the community in making decisions on planning and evaluation still receives substantial control from the government and supporting NGOs.

The varying levels of participation mean that the government has been quite successful in involving Pesanggem communities in the development of Community Forests, although in varying degrees of participation. The diversity of participation is reasonable because the Pesanggem community is not a homogeneous entity but in a heterogeneous entity. It means that the diversity of community participation is undoubtedly a result of differences in socioeconomic and institutional conditions in the local environment. These factors can be in the form of internal and external factors (institutional factors) that are sufficient to determine the level of community participation in development. Therefore, the participation of Pesanggem communities to the highest level (community control) requires quite a long time and is full of obstacles. Participation is a long and gradual process of distributing power to the people so that they get more control over their own lives [6].

\section{Conclusion}

Community participation in community forest development is not yet at the level of perfect participation, but community participation has led to the actual participation process. This situation is demonstrated by the opening of a process of mutual awareness between the government and the community. The government has allowed the community to participate fully in the development of community forests, and likewise, the condition of the community began to involve themselves at every stage of community forest development consciously. However, there are still many people who cannot participate directly because of the weakness of the institutions they have built and are less than optimal in adopting the needs and interests of the community in development.

\subsection{Recommendations}

In these conditions, modification of the existing institutions at the farmer and village government level is needed. The process towards full community participation through institutional modification of Community Forests and Villages is called "Modified Participation".

\subsection{Acknowledgement}

The authors would like to thank the Master Program of Environmental Resources Management, Interdisciplinary Graduate Program, University of Brawijaya, Malang, that 
assists authors in providing inputs, especially Dr. Drs. Djati Batoro, M.Si, and Dr. Rita Parmawati, SP., ME.

\section{References}

[1] Ministry of Environment and Forestry, Forest Status and Indonesian Forestry. Indonesia: Ministry of Environment and Forestry, 2018.

[2] S. D. Massiri, B. Nugroho, H. Kartodihardjo, and R. Soekmadi, "Preferensi Dan Motivasi Masyarakat Lokal Dalam Pemanfaatan Sumberdaya Hutan Di Taman Nasional Lore Lindu, Provinsi Sulawesi Tengah (Preference and Motivation of Local Community in Utilization of Forest Resource in Lore Lindu National Park)," J. Mns. dan Lingkung., vol. 23, no. 2, pp. 215 223, 2016.

[3] Ministry of Environment and Forestry, Minister of Environment and Forestry Regulation No. $P$ 83/2016 concerning Social Forestry. Indonesia: Ministry of Environment and Forestry, 2016.

[4] A. Firdaus, Practical Guidelines for Implementing Social Forestry Policy Framework for the Acceleration of Forest Tenure Reform. Bogor: CIFOR, 2018.

[5] K. Kuncoro, Impact of Social Forestry: Economic, Social and Environmental Perspectives. Jakarta: The Indonesian Ministry of Environment and Forestry, 2018.

[6] Y. S. Susilo, "Dampak Perhutanan Sosial Terhadap Pendapatan Masyarakat," ISEI Econ. Rev., vol. 3, no. 1, pp. 16-27, 2019.

[7] Minister of Forestry Regulations, About Community Forests. Indonesia: Minister of Forestry Regulations, 2007. 